\title{
UNIVERSITYOF
}

FORWARD

THINKING

WESTMINSTER用

WestminsterResearch

http://www.westminster.ac.uk/westminsterresearch

\section{On the Theopolitics of Sovereignty: Carl Schmitt and the theopolitics of global orders \\ Moore, T.}

This journal article has been accepted for publication and appears in revised form, subsequent to peer review and/or editorial input by Cambridge University Press in the Review of International Studies. This version is free to view and download for private research and study only. Not for re-distribution, re-sale or use in derivative works.

(C) Cambridge University Press, 2020

The final definitive version in the online edition of the journal article at Cambridge Journals Online is available at:

https://dx.doi.org/10.1017/S0260210520000054

The WestminsterResearch online digital archive at the University of Westminster aims to make the research output of the University available to a wider audience. Copyright and Moral Rights remain with the authors and/or copyright owners.

Whilst further distribution of specific materials from within this archive is forbidden, you may freely distribute the URL of WestminsterResearch: (http://westminsterresearch.wmin.ac.uk/)).

In case of abuse or copyright appearing without permission e-mail repository@westminster.ac.uk 


\title{
On the Theopolitics of Sovereignty: Carl Schmitt and the theopolitics of global orders
}

\begin{abstract}
This article considers how we can develop a reflexive reading of the theological contours of global politics through Carl Schmitt's account of sovereignty. In doing this it seeks to generate a critical architecture to understand the pluralistic registers of sovereignty within world politics. This article examines the theological dimensions of sovereignty, calling for a closer reading of the theopolitical discourses of legality and legitimacy at work within the largely secular discipline of International Relations. Tracing the pluralistic dimensions of sovereignty-juristic, popular and theopolitical-allows us to see how sovereignty is operationalised through a range of distinct political registers. When the study of sovereignty is confused with questions of preference for modes of governing (whether secular, religious, democratic, and/or juristic) the complex historical sociology of sovereignty is overlooked. Contemporary scholarship in International Relations can benefit from closer engagement with the multiple, overlapping registers of sovereignty in global politics. We may disagree with Schmitt's reading of sovereignty as 'theopolitics' but there is real methodological value in engaging secular scholarship in thinking about religion as a constitutive domain for global order-alongside a rich range of critical approaches.
\end{abstract}

\section{Theological Space in International Relations}

The historical record is replete with accounts of political actors invoking God (or 'the gods') as part of territorial claims by state-based actors. Strategic invocations of god and the sacred are not necessarily a relic of the past, although the discipline of International Relations has reached out to Thucydides in addressing the role of 'the gods' in reflecting on fates and fortunes within international politics. As the Melians plea for their survival, we are reminded by the Athenians that invoking 'the gods' (or indeed standing up for what is right against what is wrong) is itself against the dictates of political morality: "Our opinion of the gods and our knowledge of men lead us to conclude that it is a general and necessary law of nature to rule wherever one can" (Brown, et al., 2002, p. 57). Overwhelmingly the disciplinary logic(s) of international relations are secular, reflecting a Western preoccupation with progressive narratives of the Enlightenment and the quest to demonstrate how technostrategic thinking represents a progressive turn in global politics. The concept of secular political authority requires closer investigation, especially as sovereignty itself is borne out of religious conceptions of authority and how they relate to territorial entities (Shakman Hurd, 2007). The question of religion is overwhelmingly pathologised by secular scholarship which assumes that international institutions (whether international law or international political institutions) operate through agreed principles of neutrality which stand above culture, identity and religion 
in global politics. This article seeks to demonstrate how authoritative claims within Westphalian accounts of International Relations, which are seemingly 'secular', involve a complex negotiation of the legitimacy and legality of decisionist capacity in world politics. Theological conceptions of authority do not simply disappear under the weight of positivist and secular orthodoxy within contemporary International Relations theory. For this reason, Carl Schmitt's specific contribution is to demand that we read claims about the 'englobement' of international norms through the lens of suspicion, reflecting a distrust of universalizing norms within International Relations theory.

'Englobement' as simultaneously a concept, practice, and ethic of global order suggests the capacity to embrace shared norms and identities as part of the evolution of institutionalized International Relations (especially through the mechanisms of International Law). Englobement refers to the process of making meaning out of the world through the establishment of one global entity which, in itself, possesses the authority to regulate the terms and conditions of global politics. For Schmitt, no such normative device exists as the grounds of sovereignty are determined through spatialized political orders which have no claim to speak on behalf of a unified world or globe (Schmitt, 1987). It is these political orders which determine the shape and scope of international law, entailing the refusal of a universalizing order which speaks in the name of global unity. As Luca Mavelli has carefully documented it is important to problematize the epistemological and ontological assumptions which construct "secularization as an essential component of security" (Mavelli, 2012, p. 179). Central to this account of international security is the linkage of territory, whether contested or established, to discourses of sovereignty in global politics. It is argued that the idea of a post-religious international order (where religion is understood as a site of conflict rather than the source of foundational concepts within International Relations) is linked to the myth of post-sovereignty in global politics. Sovereignty matters neither less nor more than previous eras or epochs. As a temporal and spatial claim, sovereignty must be understood through decisionist capacity; namely, who is authorized to speak and act on behalf of the territorially and spatially conditioned entity we commonly understand as 'the state'?

Chowdury and Duvall have cautioned against the 'post-sovereign' (or 'non-sovereign') turn within international theory, especially as it relates to the ontology of the political subject in formulations of transgressive accounts of resistance in the horizon of political life itself. They conclude that "[i]t would be injudicious to ignore sovereignty, because not only does it come 
first, it does not go away" (Chowdhury \& Duvall, 2014, p. 219). This article seeks to identify three overlapping registers of sovereignty-juristic, popular, and theopolitical-which despite their problematic placement within territorial accounts of international politics are recognisable dispositifs of contemporary security politics, notably exceptionalism and how it conditions discourses of sovereignty in global politics of the past, present and ultimately the future. It is argued that the theological is the most hidden dimension of sovereignty and that even seemingly secular concepts in International Relations are textured in complex ways through the theological. Most relevant to the current discussion, it is argued that theology plays a decisive role in providing a justification for exceptionalism within contemporary security politics.

Drawing upon Carl Schmitt's account of political theology, it is possible to understand how both the norms and dynamics of political order-especially at the level of ontology and epistemology - are enabled through inadvertent expressions of faith, spirituality and the religious within key concepts within International Relations. Giving careful consideration to the ways in which the secularised vocabularies of global order are emergent from within a theological frame allows us to think differently about core concepts and practices within IR. For example, examining how security exceptionalism (where military security is taken as the primary object of security) is enabled through a theological domain is of methodological value when religion, faith and, the politics of religious fundamentalism are routinely expressed through discourses of 'danger' in global politics. This article argues that we need to play close attention to the relationship between the temporal (the seen) and the spiritual (the unseen) which conditions our understanding of sovereign decision-making. Paying attention to the popular, juristic and theological domains of sovereignty in equal measure potentially allows for a rebalancing of sovereignty beyond its populist domain in contemporary global politics. More crucially, it is important to challenge the predominance of the secularist ethic in International Relations which associates secularism with a progressive narrative of global order. Presenting a critical archeology of sovereignty involves the refusal of 'religion as variable' approach to global politics, revealing how theology functions at the ontological and epistemological level—often without states, people and International Relations theorists actually knowing it.

Mika Louma-Aho has noted, in examining the turn to religiosity in the aftermath of the 9/11 attacks and the ensuing War on Terror, that the European body politic has been a site of 
contestation between Western Christianity and Empire (Louma-Aho, 2009). The biblical origins of political community are part of the dynamic relationship between Empire and Christianity in the European context, although clearly its reach extended well beyond Europe through subsequent histories of colonialism and the cultural dispossession of indigenous peoples. Developing an understanding of the disciplinary tendency to generate mythologies of the person through the state (Thomas Hobbes' Leviathan is the most prominent example) it is noted that IR theorists themselves are engaged in the production of a certain type of religion or theology around 'the international'. In terms of specific manifestations of global insecurity, the interactionist model of global politics-where national interests jockey for power within a territorialized realm-involves the disciplinary production of a specific narrative which can be understood as a theological order. As Mika Louma-Aho notes in relation to the "theology of IR': "Our gods do not leave their punishments and rewards to afterlife: the states we live and believe in can release hell on earth, and have done so, over and over, the world over" (LoumaAho, 2009, p. 308).

It is important to understand how discourses of salvation, whether religious or secular, occupy a strategic role in the legitimation of the state as the organizing principle and decisive political entity in International Relations. In documenting the manifestations of violence in global politics, William $\mathrm{T}$ Cavanaugh has refuted the notion that religion necessarily produces violence. On the contrary, Cavanaugh's focus on soteriology (concerning the doctrine of salvation and how these narratives condition certain types of political rationalities around the functioning of the state) highlights how the state has itself used salvation as a vehicle for conquest, war and enslavement of indigenous peoples and communities: "The myth of the wars of religion is also a soteriology, a story of our salvation from mortal peril" (Cavanaugh, 2009, p. 123). What Cavanaugh refers to as the soteriology of the state illustrates how doctrines of authority, whether secular or religious, are enabled through salvation. Nonetheless, religious doctrines of salvation are increasingly replaced by secular variants of salvation since "the foundation of the state is based on the widely-accepted myth about the necessity of the state to save Europe from the 'Wars of Religion' in the sixteenth and seventeenth centuries' (Cavanaugh, 2002, p. 9). Contractarian accounts of political community-Locke, Hobbes, Rousseau-can be read as the analogous narratives of the earlier theological traditions of Western Christianity. Stories of creation, fall and redemption are an inherent part of the theological imagination of world religions (especially Christianity and its many conflicted variants). Equally so, the modern state has used narratives of salvation as a means to produce 
political subjectivities which embody the consumer model of (in)security so attached to Westphalian security politics. The focus on salvation can also be related to the functionalist rendering of the state, whether in Max Weber's classic formulation of the state as possessing 'monopoly on the legitimated use of physical force' (Weber, 2004) or Charles Tilly's less sanguine reading of the state as a 'protection racket' (Tilly, 1985).

What is new in this account of Schmitt's political theology of sovereignty is that it positions itself at a critical distance from those who seek to revive Schmitt for the purpose of imagining a multipolar world constituted through agonistic (power) relations. The revival of Carl Schmitt, well documented in this journal and elsewhere, was inscribed with a particular purpose within radical democratic theory; namely, to understand how the friend-enemy dialectic can enable new forms of engagement with the Other in contemporary political thought (Mouffe, 1999). The approach taken in this article is to deploys Schmitt's taxonomy on sovereignty and theology to make sense of our own anxieties and dilemmas concerning the status of religion and theology in International Relations theory today. In this regard, the article does not accept the teleological claims of Schmitt's conception of political community but, in keeping with a need to understand the hierarchical ordering of concepts within International Relations, seeks to unpack how sovereignty operates through categories which exceed secular logics. It should be noted that the resurgence in sovereignty within global politics - whether at the borders of Calais, the symbolic walls of Trump, or demands for a 'blue, red, and white Brexit' - demonstrate the need for greater reflexive engagement with the terms, conditions, and limits of sovereignty.

This article is structured to reflect an engagement with Carl Schmitt's theological writings, linking these to a broader understanding of geopolitics and religion within contemporary International Relations. The first section examines how sovereignty has become fashioned through secularism and why we need to deploy a pluralistic methodology for understanding global order. In calling for an appreciation of the 'theological space' within IR it is important to rethink religion as a 'variable' within global politics. The next section examines why we need to focus on how sovereignty is enabled through a range of 'sovereign' discourses-juristic, popular, and theopolitical —in order to avoid the methodological trap of treating 'secular' sovereignty as the only valid and legitimate sovereignty within global politics. The discussion concludes by calling for an appreciation of the codes (or understandings) of theological space within and outside International Relations. The liberal rendering of a 'rules-based order' fails to appreciate the critical role of theology in both theories and practices of world politics 
(something which the late Nick Rengger dedicated a significant body of his work towards addressing).

\section{Sovereignty and the Secular}

The selection of 'sovereignty' as a vehicle to understand how the theological informs the seemingly secular within International Relations reflects the fact that sovereignty is nearly always taken as a given within global politics. Declarations of sovereignty are imbued with a semi-religious significance in the political world. From the Brexit catch cry of "Take Back Control" or invocations to "Make America Great Again" it is important to think critically about the liminal spaces of sovereignty in global politics. For those political communities who lack the formal dimensions of sovereignty, in the sense of Walzer's legalist paradigm where territorial integrity and political sovereignty are regarded as the primary aspirations of political actors, it is important to think about how the seemingly secular practices of statecraft are products of religious movements, Empire and dispossession in global order (Walzer, 2015). What we should take from Schmitt's reading of sovereignty is the importance of originary mythologies in constituting the modern state form today.

"Sovereign is he who decides on the exception" Schmitt declares in the opening paragraph of Political Theology (Schmitt, 1985, p. 5). Formulating the concept of the political in terms of the exception involves a theologically driven account of politics than that contained in the friend-and-enemy grouping. For this reason, it is important to consider how theology establishes Schmitt's exceptional concept of the international and, in so doing, undercuts the very ambition of a concept of the political derived autonomously (Moore, 2010). Theology gives Schmitt's concept of the political its decisiveness, allowing it to bring order to the inherent anarchy associated with the exception. Related to Schmitt's theological rendering of the political, identified here as Theopolitik, is a claim about the need for a decisionist ethic in both legal and international theory. This decisionist ethic is not just confined to defining the amity lines of political community but also, more broadly, concerned with the conditions under which order itself is attained. Schmitt thinks that the liberal model lacks this decisionist capacity since it operates in terms of impersonal rules rather than acting decisively in terms of decision.

Schmitt's account of sovereignty works in terms of the exception. Sovereignty is defined as 
he who decides on the exception. Schmitt thereby links sovereignty to the borderline case. "The definition of sovereignty," Schmitt notes, "must therefore be associated with a borderline case and not with routine" (Schmitt, 1985, p. 5). Schmitt contests the value of the liberal jurisprudential model, especially its tendency to look to the norm as a means of determining conduct in the emergency. Exceptions to the rule are more powerful determinants of political right and conduct than the rule itself: "The exception, which is not codified in the existing legal order, can at best be characterised as a case of extreme peril, a danger to the existence of the state, or the like. But it cannot be circumscribed factually and made to conform to a preformed law" (Schmitt, 1985, p. 6). Sovereignty thus refers to a higher power, not a derived power in which subjects authorise another to act on their behalf. Sovereignty cannot be reduced to popular decision, resolved democratically through participatory forms. Sovereignty consists in the "concrete application" of the decision. The sovereign is thus defined as he "who decides in a situation of conflict what constitutes the public interest or interest of the state, public safety and order, le salut public, and so on" (Schmitt, 1985, p. 6).

The sovereign thus enjoys a formal, decisionist role that involves a concept of the political that is not just confined to the concrete friend-and-enemy grouping. Sovereignty (and the sovereign) is without limits because the question about what constitutes the public interest or interest of state or public order and safety can never be foreclosed. It is the very concept of the exception that allows the sovereign to achieve his sovereignty. "It is precisely the exception," Schmitt argues, "that makes relevant the subject of sovereignty, that is, the whole question of sovereignty. The precise details of an emergency cannot be anticipated, nor can one spell out what may take place in such a case, especially when it is truly a matter of extreme emergency and of how it is to be eliminated" (Schmitt, 1985, pp. 6-7).

For Schmitt, modern constitutionalism wants to eliminate the sovereign question from the political. A belief in the regulative capacity of law - Grotius, Kant, and Kelsen - means that law becomes the primary means by which a political community establishes public order and safety. Using the rule of law to determine the content of the political decision involves the disavowal of the sovereign and sovereignty. The exception cannot be removed from the world by juristic means. Schmitt's exception is expressed in terms of a sublime, symbolising the highest region of both political conduct and knowledge. The exception stands outside a normally valid legal system. But it is not necessarily the case that this ontological condition (standing outside the norm) cannot contribute anything to the normative order more generally. 
It is the exception that defines the content of the norm, allowing the sovereign to decide when and whether "the constitution needs to be suspended in its entirety" (Schmitt, 1985, p. 7). For Schmitt, placing the emphasis on the sovereignty of law or the sovereignty of the people is inherently problematic. This is because sovereignty involves the final determination of an order. Looking to the people (popular sovereignty) or to the law (juristic sovereignty) is insufficient for the functional role that sovereignty plays in determining when normal law should be suspended under emergency law or "states of exception".

It should be noted that this article seeks to understand the theopolitics behind sovereignty through the writings of Carl Schmitt. It does not, however, seek to maintain Schmitt's priority of the theological over the the popular or the theological over the juristic. On the contrary, the intention is to underscore the multiple articulations of sovereignty within global politics and how these plural understandings are essential for making sense of the diverse textures of sovereign utterances within the practices, processes, and dominant ontologies of the contemporary state system. It is indisputable that both 'law' and 'the people' have become an important element of the conceptual vocabulary of sovereignty. It is argued that under the guise of secularism the dominant methodological frameworks within IR have failed to understand how many of the prejudgments within IR are encoded and enacted within theological space. Sovereignty (or more correctly, sovereignties) provide an important structure of address for making sense of the supposed limits between the normal and exceptional within global politics.

In this regard, Schmitt admires Jean Bodin (1530-1596) for linking sovereignty to the practical concern of state stability. Sovereignty cannot be understood juristically but emerges as practical conduct and knowledge when a normal order is overpowered by the exception. The fact that Schmitt talks in terms of the exception (defined at various times as the borderline case, the critical case, the extreme case, and the dire emergency) means that the concept of 'sovereignty' is located in a domain which exceeds the contemporary; that is to say, sovereignty does not depend upon pre-understandings that circulate widely within discourse but on conditions that miraculously present themselves as dilemmas that require the authority of the sovereign. Bodin is significant for Schmitt because although working within a natural law tradition Bodin allows for the suspension of universal law in the emergency. According to Bodin, Schmitt notes, "the prince is duty bound toward the estates or the people only to the extent of fulfilling his promise in the interest of the people; he is not so bound under conditions 
of urgent necessity" (Schmitt, 1985, p. 8).

According to Schmitt, the sovereign is not duty bound to obey law (juristic sovereignty) nor the will of the people (popular sovereignty) but called to be decisive when the stability of a dominant order is called into question. In view of this fact, Schmitt notes that sovereignty itself disappears when it must answer to another: "If in such cases the prince had to consult a senate or the people before he could act, he would have to be prepared to let his subjects dispense with him" (Schmitt, 1985, pp. 8-9). Sovereignty, as an expression of the decisionist capacity of the political, involves the immunity of the prince vis-à-vis the principality. The mark of sovereignty, Schmitt suggests, is the "authority to suspend valid law" (Schmitt, 1985, p. 9).

The Schmittian account of sovereignty does not think of sovereignty in terms of law (juristic sovereignty) or the power of the people (popular sovereignty). For Schmitt, there is a capacity problem at the heart of liberal thinking, whether liberal international law or liberal institutions, to adapt to the political challenges associated with decisionist politics. The liberal model attempts to make bellum omnium contra omnes (the highest expression of emergency politics) the routine business of constitutional politics. Yet the solutions offered by this approach to politics, whether national and/or international, fail to recognise the importance of suspending normal regimes when the political order is threatened by external or internal forces. Liberalism lacks the ability to address problems of global political (dis)order-whether war, dispute, and/or disagreement-because the means it has at its disposal is woefully inadequate for the concrete task of dealing face-to-face with enmity in world politics. This way of thinking about international politics, where problems of order can be resolved through popular will or through the rule of law, is problematic according to Schmitt. Law itself is not the product of norms; rather, what constitutes law is dependent on the decision. The claim being advanced by Schmitt is that norms are products of decisions: "Like every other order," Schmitt announces, "the legal order rests on a decision and not on a norm" (Schmitt, 1985, p. 11).

Schmitt thereby links sovereignty to the question of competency and action when the state is confronted with the supreme emergency (where emergency situations are called into being by those with decisionist authority). Legal competency is defined as he [sic] "who is competent to act when the legal system fails to answer the question of competence." Sovereignty involves answering the following question: "Who is responsible for that which has not been 
anticipated?" (Schmitt, 1985, p. 10). Schmitt's account of sovereignty involves answering the question about who has competency when the legal system is in question. The juristic account of sovereignty (where sovereignty is expressed through legal agreement, codified through the rule of law) is unable to fulfil this role according to Schmitt. Juristic sovereignty stresses the equality of persons before the law; since all are equal before the law then individual claims about truth are always valid claims and inherently irreconcilable. In many respects, this popular dimension of truth rationalization can be read as a justification for expert knowledges (and possibly an oblique critique of post-truth politics). Popular sovereignty stresses the capacity of a people to collectively determine the field of political possibility and the upshot of deliberative agreement in the public sphere will determine the scope of action on the international stage. Nonetheless, since liberalism conceives of the people pluralistically Schmitt thinks it impossible for a people to generate an overarching framework to secure public order and safety. Sovereignty suffers when conceived in terms of either a juristic ethic or a popular ethic. This is reflected in Schmitt's claim that a "jurisprudence concerned with ordinary day-to-day questions has practically no interest in the concept of sovereignty" (Schmitt, 1985, p. 12).

The liberal register of sovereignty, where jurisprudence regulates disagreement through normal conceptions of law, is predicated on legality as established through routine. A normbased approach to law can be seen in liberal international law, where norm formation (and norm entrepreneurs) generate consensus about shared values or processes which govern the business of world politics. Whilst this liberal approach establishes a spatialized legal framework to understand certain types of conduct (and misconduct) in global politics it does not necessarily reveal the production and reproduction of values beyond the routine. For Schmitt, the exception produces a higher form of legality than that associated with legality produced through juristic sovereignty and/or popular sovereignty. Schmitt claims that " $[\mathrm{t}] \mathrm{he}$ exception is that which cannot be subsumed; it defies general codification, but it simultaneously reveals a specifically juristic element-the decision in absolute purity" (Schmitt, 1985, p. 13). This dual ontology means that law, construed as codified legality, is associated with a lower type of legality: "Every general norm demands a normal, everyday frame of life to which it can be factually applied and which is subjected to its regulations. The norm requires a homogenous medium" (Schmitt, 1985, p. 13). The exception cannot be framed in relation to everyday life and, because it does not manifest itself through a normal regime, lacks an immediate ontology. The use of a normal regime to combat chaos is thus specifically 
rejected by Schmitt: "There exists no norm that is applicable to chaos. For a legal order to make sense, a normal situation must exist, and he is sovereign who definitely decides whether this normal situation actually exists" (Schmitt, 1985, p. 13).

Schmitt's exceptional account of sovereignty stands in direct opposition to Lockean and Kantian conceptions of the constitutional state. Attempting to regulate the exception places too much faith in the capacity of rationalism to moderate political knowledge and conduct. Regulation of the exception can also be understood, in Schmittian terms, as the betrayal of the very notion of sovereignty. Thus, "[e]mergency law was no law at all for Kant. The contemporary theory of the state reveals the interesting spectacle of the two tendencies facing one another, the rationalist tendency, which ignores the emergency, and the natural law tendency, which is interested in the emergency and emanates from an essentially different set of ideas" (Schmitt, 1985, p. 14). Schmitt associates rationalism with an inability to come to terms with the exception, manifested in the claim that "the exception proves nothing and that only the normal can be the object of scientific interest". This is given its clearest articulation by Schmitt when he claims that in order to study the general you need to be alert to the extreme boundaries of the exception:

It [the exception] reveals more clearly than does the general. Endless talk about the general becomes boring: there are exceptions. If they cannot be explained, then the general cannot be explained. The difficult is usually not noticed because the general is not thought about with passion but with a comfortable superficiality. The exception, on the other hand, thinks the general with intense passion (Schmitt, 1985, p. 15).

Schmitt's exceptional notion of political sovereignty affirms the importance of philosophy which takes a concrete form: "Precisely a philosophy of concrete life must not withdraw from the exception and the extreme case, but must be interested in it to the highest degree" (Schmitt, 1985, p. 15). Schmitt links the development of a 'philosophy of concrete life' to the need for the sovereign to determine the conditions by which a normal legal regime can be suspended. The exception involves a concrete relationship to the world because of the fact that it challenges the normative precepts that regulate the liberal jurisprudential model of global politics. Schmitt works from the presupposition that the exception is more interesting than the rule and, in so doing, associates the exception with a higher form of legality than that advanced through systematic approaches to international law and politics. The fact that the exception gives deeper insights into legality than the rule affirms the dual ontology of legality advanced 
by Schmitt. This leads Schmitt to claim that "[t]he rule proves nothing; the exception proves everything: It confirms not only the rule but also its existence, which derives from the exception" (Schmitt, 1985, p. 15).

The Schmittian vision of sovereignty is in stark opposition to the normative recoding of sovereignty in liberal jurisprudence. Hans Kelsen seeks to demonstrate why thinking of sovereignty in terms of supreme power or supreme order represents a partial view of sovereignty. "To be sovereign," Kelsen declares, "seems to be incompatible with being subject to a normative order; thus to maintain the idea of the state as a supreme authority this term is understood to mean only a supreme legal authority, so that 'sovereignty' of the state means only that the state is not subject to its own legal order" (Kelsen, 1969, p. 115). Kelsen is concerned that this type of thinking, as is contained in Schmitt's exceptional notion of sovereignty, results in sovereignty being denied its normative status. The Schmittian account of sovereignty thinks of the sovereign as a "kind of superman or superhuman organism" (Kelsen, 1969, p. 115). Kelsen takes issue with this extreme hypostatization of sovereignty. This is because Kelsen understands law as the artefact of human will not, contrary to Schmitt, the product of an exceptional lawmaker who determines when law itself can be suspended. This is reflected in Kelsen's understanding of law, especially at the international level. "What we call society or community," Kelsen declares, "is either the factual coexistence of individuals or a normative order of their mutual behaviour" (Kelsen, 1969, p. 115). This can be contrasted with the Schmittian concept of sovereignty which, owing to its exceptional nature, dismisses the capacity of normative order to generate political community. Schmitt works from the premise that normative order is always conditional on a higher form of legality, emerging only through the exception: "In the exception the power of real life breaks through the crust of a mechanism that has become torpid by repetition" (Schmitt, 1985).

Schmitt claims that Kelsen's normative science places too much emphasis on the normative and, for this reason, it is unable to derive legality from the concrete experience of the exception. According to Schmitt, "Kelsen solved the problem of sovereignty by negating it" (Schmitt, 1985, p. 21). Schmitt associates this negation of sovereignty with Kelsen's desire to turn sovereignty into a normative rather than an exceptional order. Asking that sovereignty be assessed in terms of how an authoritative order is established through real human wills challenges the Schmittian notion of sovereignty which depends on the existence of an exceptional will. The purity of law, as bound up in Schmitt's notion of legality as the chance 
to compel obedience, involves the sovereign being in a position to determine when normal conditions of legality can be suspended. Thus, Schmitt's exceptional account of sovereignty is incompatible with Lockean conceptions of law. Locke distinguishes law from commission; the former expresses legality through a process of contract and authorisation, the latter understands legality as derived from divine monarchical right. Both Locke and Kelsen, as defenders of the liberal model, reduce legal prescription down to how decisions are to be made; to the detriment of who should decide:

But he [Locke] did not recognize that the law does not designate to whom it gives authority. It cannot be just anybody who can execute and realize every desired legal prescription. The legal prescription, as the norm of decision, only designates how decisions be made, not who should decide. In the absence of a pivotal authority, anybody can refer to the correctness of the content. But the pivotal authority is not derived from the norm of decision. Accordingly, the question is that of competence, a question that cannot be raised by and much less answered from the content of the legal quality of a maxim (Schmitt, 1985, pp. 32-33).

Who or what has competency has significant implications for the practice and discipline of International Relations. With authority understood as driving legitimacy (rather discourses of truth or what is right) the image of legal personality established by Schmitt is unapologetically elitist in its origins as well as its consequences. At its core is the theopolitics of the sovereign which stresses the importance of keeping the most extreme articulation of sovereignty beyond the reach of normal regimes of law and/or away from 'the people' (who can't be trusted!). It should be noted that Schmitt's hierarchical ordering of sovereignty fails to appreciate the overlapping registers of sovereignty which he himself understood as aspects of sovereignty, albeit with differing degrees of political efficacy. Schmitt's theopolitical approach-even in spite of its privileging of theology above the rule of law and 'the people'-highlights the importance of scholarship in IR which contests the modalities and mythologies of sovereignty carefully. We do not have to agree with Schmitt about the hierarchical ordering of sovereignty with theology at its apex, but there is value in examining how secular orders have generated their own mythologies about legality, legitimacy and political agency within global politics. Having considered how 'to read' hierarchies of sovereignty the next section considers why religion and theology must be understood as constitutive of world order (not just as variables in global politics).

\section{Rethinking Religion as a 'variable' within IR}


Religion has too often been regarded as a 'variable' within international politics without due acknowledgement of the systematic theological logics at work within the 'mechanics' of global politics itself. In a survey of the placement of religion within International Relations, Sandal and James (2011) focused on the role of religion vis-à-vis mainstream theories of international politics. Their focus on how religion should be understood through the frameworks of classical realism, structural realism and neoliberalism reflects this 'variable' based approach to religion and theology in contemporary International Relations. Most remarkably, treating religion as an identity-claim (alongside race, ethnicity and gender) means that identity is not understood as a constitutive dimension of power, governance, and sovereignty in world politics. Linked to this 'variable' based approach (where religion is conceptualised as a phenomena of international relations) is the failure to grasp the coconstitutive nature of religion and norms within International Relations more broadly. Focusing on the question of sovereignty, its religious origins, is the primary focus of this article. The objective is to encourage deeper reflection on the epistemological and ontological dimensions of theology within the discipline of International Relations. By moving beyond the conscious (or observable) deployment of religious practices or theology within the space of global politics it is possible to see the extent to which conceptions of faith, religion and theology are reflected in foundational concepts and practices within global politics itself.

According to Sandal and James (2011, p. 6), "religious phenomena should be investigated as an independent (as a cause), intervening (as a link between the cause and the resulting observation) and dependent variable (as the 'product' of non-religious causes)". This article still acknowledges the need for IR scholars to investigate the deep causal, relational and/or interdependent interactions which are carried out in the name of religion, religious traditions and theologies. It does, however, in focussing on Carl Schmitt's theological syntax of sovereignty suggest the need for a critical awareness of how practices which are seemingly secular received their original meaning through theological worlds. Schmitt's concept of sovereignty stresses the need for the state to determine, with concrete clarity, the conditions by which a normal legal order can be suspended for the sake of securing a higher level of public order and safety. The question of who is compelled to decide is accorded greater significance than how decisions are to be made. Schmitt's concept of sovereignty remains loyal to the notion of the sovereign; sovereignty cannot be shared democratically (popular sovereignty) nor reconfigured normatively through the rule of law (juristic sovereignty). 
Sovereignty involves the identification of legal competency when a normative order has been suspended and/or ceases to provide an authoritative structure for decision-making. The liberal jurisprudential model, Schmitt argues, is useless when confronted with a constitutional emergency; its desire to establish a legal order through normative maxims involves the very negation of the concept of sovereignty. Sovereignty cannot be recodified through normative prescription and, for this reason, the liberal model cannot sufficiently respond to the concrete urgency of the decision. Schmitt is adamant that sovereignty is a practical rather than an abstract discourse involving real questions about who is competent to act rather than normative considerations of political and/or legal right. A fundamental limitation of Schmitt's assessment of sovereignty is that the definition of sovereign competency is determined largely by this theological vision of the world. Sovereignty cannot be understood autonomously-in terms of its specific tensions-but only makes sense when phrased in theological terms. Sovereignty can be understood as a form of international (political) theology for the sole reason that:

\begin{abstract}
All significant concepts of the modern theory of the state are secularized theological concepts not only because their historical development-in which they were transferred from theology to the theory of the state, whereby, for example, the omnipotent God became the omnipotent lawgiver-but also because of their systematic structure, the recognition of which is necessary for a sociological consideration of the concepts. The exception in jurisprudence is analogous to the miracle in theology. Only by being aware of this analogy can we appreciate the manner in which the philosophical ideas of the state developed in the last centuries (Schmitt, 1985, p. 36).
\end{abstract}

Documenting the origins of the state, through the emergence of philosophical ideas of the state, has played a key role in the legitimation of International Relations as a discipline. Carl Schmitt's concern with the theopolitical workings of sovereignty establishes a systematic relationship between international jurisprudence and theology. Mika Luoma-Aho has called for a fundamental reframing of International Relations in challenging the secular narrative of global politics. Not only does this fundamentally challenge the variable-based approach to religion, as something which is done to people or something which people do, it also calls for a critical reading of the dogmatism of scholarship within International Relations. International relations functions as a religion and the state is its god: "What this makes IR-the-discipline is a theology of sorts, hiding under the canopy of secular social science" (Luoma-Aho, 2012, p. xiv). 
A similar story can be gleaned from the theoretical frameworks developed by scholars of International Relations, for whom secular reasoning expresses the logic of international institutions and political processes at the international level. If religion is to be invoked, then this is primarily as an explanatory model for understanding conflict or for making sense of the evolution of the modern state system as a progressivist narrative. Fukuyama has claimed that "the secular ideas of the Enlightenment eroded belief in religion as such" (Fukuyama, 2011, p. 289). Such texts are littered with progressivist claims, largely functioning to reinforce the power relations of colonialism, that secularism is a political ethic which belongs to modernity and expresses true human progress. For this reason, there is value in thinking about whether religion disappears under the weight of secularism (and secularization) or whether religious orders continue to exert their influence on political communities irrespective of whether they are intentionally religious or not. The concept of sovereignty is one such litmus test, allowing us to consider the extent to which sovereignty is produced (and reproduced) as a human endeavor through norms (Kelsen) or whether sovereignty is an emergent concept that makes itself concretely known only when the state is faced with threats to its security (Schmitt).

For Hans Morgenthau, the question of establishing international jurisprudence (through the rule of law at the international level) or universal claims to morality (through shared understandings of international morality) will always be subject the dictates of the national interest. Kelsen's ambition to establish norms which regulate the interactions between state and non-state actors will necessarily fail at the juncture where national ethics professes to speak as international ethics. As Morgenthau observes, "[ $t$ ]he moral code of one nation flings the challenge of its universal claim into the face of another, which reciprocates in kind". (Morgenthau, 1960, p. 256). Kelsen's patterning of sovereignty stresses the way in which norms are the product of intersubjective agreement concerning the validity of a given order. Kelsen assesses the validity of norms in the following terms: "Norms are valid for those whose conduct they regulate." This leads Kelsen to claim that jurisprudence "sees the law as a system of general and individual norms" and, for this reason, he claims that "facts are considered in this jurisprudence only to the extent that they form the content of legal norms." Schmitt rejects Kelsen's normative reconfiguration of legality on this basis that it rests upon a normative lawfulness rather than lawfulness established through the exception. According to Schmitt, Kelsen's concept of legal order is "based on the rejection of all "arbitrariness," and attempts to banish from the realm of the human mind every exception" (Schmitt, 1985, p. 41). 
It is important to separate questions of the origins or sources of different political registers of sovereignty from the consequential logics of sovereignty. If the origins of one version of sovereignty are deemed to be more legitimate according to the field of justification (e.g. popular sovereignty as a trump against theopolitical sovereignty) then this potentially overlooks the inherently political ontology of sovereignty itself. Whilst Suganami has also addressed the importance of coming to terms with both Schmitt and Kelsen for understanding the production of international law it is, nonetheless, important to resist the temptation to label one political register of sovereignty as necessarily more benign or more violent than each articulation. For example, Suganami notes that "Kelsen's conception is relatively benign and points to the historically contingent (and therefore potentially evolving) content of international law, giving an impetus to a historical study of the evolution of legal norms" (Suganami, 2007, p. 530). Whilst such normative judgements can assist us in processing the different sorts of originary myths of sovereignty - from the "omnipotent lawgiver" to the "jurist" to "the people" - it is worthwhile noting that in constituting sovereignties as overlapping political registers the focus is on how sovereignties enable exceptional discourses of (in)security in global politics. Populist understandings of sovereignty can author violent ontologies as deeply violent and politically dehumanizing as theopolitical registers of sovereignty. Equally so, as Guantanamo Bay demonstrated there is sufficient space for juristic registers of sovereignty, constituted under liberal regimes of international law, to deliver real physical harm and epistemological violence as theopolitical registers of sovereignty. Perhaps it is the case the tendency to be more benign or more violent are themselves irrelevant when the boundaries between normal law and exceptional law are crossed.

It should be noted that Schmitt's account of sovereignty is normative to the core; that is, in establishing the exception as the definitive embodiment of sovereignty the teleological ends of sovereignty entail the violent subjugation of the people (popular sovereignty) and the rule of law (juristic sovereignty). Anne-Marie Slaughter has argued that "liberal international relations theory creates analytical space for both individuals and groups operating in domestic and transnational society and states, and conceptualizes them in relation to one another" (Slaughter, 1995, p. 742). For Schmitt, this conceptualization of an international spatial order would entail the rejection of the most decisive aspect of sovereignty (its capacity to generate a decision under the weight of the emergency situation).

In many respects, Schmitt's reading of the theological register of sovereignty helps expose the 
myth of secular orders which permeates geopolitical thinking about identity and difference within global politics. The pathologizing of comparative religions, without referencing the theopolitical starting points of 'Western' traditions and modes of theological being, needs to be addressed as a fundamentally hostile act towards the Other within International Relations. Seyla Benhabib has resolutely claimed that "in addressing our politico-theological predicament Carl Schmitt is of little use" (Benhabib, 2010, p. 455). In considering the revival of religion in global politics, Benhabib has identified the 'politics of veiling' as a primary example of how political meanings are negotiated and renegotiated through time, space and culture: "The politics of the scarf has become a transnational struggle, revealing complex moves and counter-moves taking place among the sovereignty of the secular state, constitutional negotiations, and the symbolic markings of the female body" (Benhabib, 2010, p. 457). Yet Benhabib is confident that these struggles over meaning (and most worryingly, women's bodies) are resolvable within the horizon of 'overlapping [democratic] consensus' . The myth of secularism is firmly anchored in Benhabib's call for democratic citizens to utilize 'democratic iterations' (via Derrida) to address the changing frontiers of human rights in Western, democratic political culture. Nonetheless, Benhabib's premature rejection of Carl Schmitt's thinking on religion, political theology and discourses of exceptionalism illustrates how secularism has allowed itself to flourish as a self-fulfilling prophecy of global politics. It is for this reason, as the section below details, that we need to be open to the theological if we are to understand the constitution of global order more broadly.

\section{When IR Encounters Theological Space: Rethinking Theories and Practices}

Reinhold Niebuhr spoke of a class of people who professed greater awareness of the limits of nationalism and national interest within political communities (as compared to those with ordinary, everyday lives): "There is always, in every nation, a body of citizens more intelligent than the average, who see the issues between their own and other nations more clearly than the ignorant patriot, and more disinterestedly than the dominant classes who seek special advantages in international relations" (Niebuhr, 2005, p. 57). We should clearly resist such elitism in assuming the seduction of the masses through populism, but there is value in dislocating the secular account of sovereignty in International Relations as the moment in which religion is cast aside in favour of secular international law (liberalism) and/or the business of technocratic statecraft (realism). In terms of critiquing liberal world order, this article seeks to demonstrate how religion should not be understood only as a variable to explain conflict in world politics (and, in so doing, turning religion 
into a pathology). On the contrary, religions and theologies establish a constitutive grounding for the terms of (global) political discourse and the secularisation of sovereignty has involved a forgetting of the ways in which power has been mobilised through both temporal and theological domains of sovereignty.

Contemporary critics of liberalism in International Relations have rightly deployed Schmitt to document the collapse of Westphalian conceptions of global order. Louiza Odysseos and Fabio Petito rightly identify the dangers of reading Schmitt through one discipline. Schmitt's work, they argue "... lies at the intersection of international relations, international law, and international history, while drawing at the same time on philosophy and political and legal theory intersections" (Odysseos \& Petito, 2006, p. 2). Whilst their focus was on the contesting the hegemonic formulations of global order, specifically in terms of the Global War on Terror, there is a need to also extend the analysis to consider the ways in which these disciplines have themselves been colonised by secular assumptions about the constitution of world order. In other worlds, in overlooking religion and theology as an element of ways of thinking about states, sovereignty, and (global) orders in world politics there is a risk that we bifurcate the world into a progressivist narrative of the secular. Overlooking the theological and reinforcing the secular-regardless of one's faith or indeed lack of faith-comes with attendant problems for scholars of International Relations.

Although Schmitt's account of political theology is primarily contained within two primary works-Political Theology: Four Chapters on Sovereignty and Political Theology II: The Myth of Political Closure-it is important to contextualise the significance of this 'theopolitical' mode within his broader account of spatialised international order and his determination to expose the normative limits of a consensus-based international legal order. We should be careful of accepting Schmitt at his 'face-value' and presuming that his conceptual rendering of the political in terms of the friend-and-enemy distinction maintains the distinctiveness of the political vis-à-vis other domains (e.g. religion, culture, economy, law, science) (Schmitt, 1996, p. 23). Whilst Schmitt explicitly isolates the political as distinct from a religious mode in his landmark text The Concept of the Political it is acknowledged that religion has the potential to be political only when it transforms itself through enmity. "Every religious, moral, economic, ethical, or other antithesis transforms itself into a political one if it is sufficiently strong to group human beings effectively according to friend and enemy" (Schmitt, 1996, p. 37). Nonetheless, as Schmitt himself contends, notions of political will and political agency are dependent upon 
theologies of being which establish a moral flaw in the human condition. Schmitt's Catholicism commits him to make sense of human agency in terms of 'original sin' and, in so doing, presupposes a fallen and failed vision of human conduct: "[a]ll genuine political theories presuppose man to be evil" (Schmitt, 1996, p. 61).

The entrenched narrative of international order as an anarchical space (a prominent part of the so called 'great debates' within IR in the 1920s and 1930s) has largely overlooked the fact that its own theoretical house has been constructed out of the vestiges of political theology. Schmitt's writings remind us of how 'realist' International Relations rests upon the "fundamental theological dogma of the evilness of the world" (Schmitt, 1996, p. 65). Political sovereignties-whether theological, juristic, and/or popular-are all expressions of worldviews about the nature of political agency and the scope of political institutions to regulate these through both procedural and normative fraemworks. These worldviews constitute the political theology of IR theory itself, unleashing specific grammars of power which contain within them codes and practices of the theopolitical past, present and future. These worldviews cannot be viewed in isolation from the historical role of both Church and State in establishing the geopolitical contours of modern political existence. We may profess to offer a scientific theory of international politics, informed by secular principles of 'value neutrality', but it is important to think about how the very foundations of International Relations are shaped by an array of (theological) landscapes. Schmitt directs us to think about the political in terms of the friend-and-enemy grouping, suggesting an inescapable 'logic of the political' (Schmitt, 1996, p. 79). Schmitt's observations on political theology suggests that sovereignty itself is encoded in the normative practices of states at the international level. The purpose of underscoring this theological dimension is not to endorse a theological (or 'theopolitical' reading of global politics) but to remind observers of global politics of how the religious functions as a constitutive domain of sovereignty and statecraft.

We may have moved beyond the bellum sacrum era where 'holy wars' provided one way of reading geopolitics, but as Schmitt argues in relation to World War 1, "[t]he experiences of the world war against Germany have shown that wartime propaganda in no way dispenses with the moral convictions that are normally only acquired from a Crusade" (Schmitt, 2011, p. 31). The very notion of war as a crusade (where war is understood as the art of crusading) may have disappeared under the weight of positivist international law but the establishment of legal universals (or norms of international law) indicates the inherent particularism of justice within 
the global sphere. Schmitt anticipated many debates about the selectivity of humanitarian intervention and the limits of universalism in global politics, especially in relation to minority rights and how these reflect the objectives of the dominant order rather than a universal order. The so-called 'universal' norms of international law should not be understood as "systematics of international law" but understood instead as examples of a "systematic conceptual geography" (Schmitt, 2011, p. 36). The geopolitical constellations of international law reveal how law operates as a discourse of power within global politics, with claims about justice (as well as legality, legitimacy, and sovereignty) being determined by the material conditions of land and sea within world history (Schmitt, 2015).

Schmitt provides a two-pronged attack on the idealism of international lawyers on the one hand (who seek to demonstrate that international legal norms can regulate the conduct of states) and the global constitutionalism of diplomats on the other (who seek to demonstrate that international legal norms can bring people together through an 'international community of peoples') (Schmitt, 2011, p. 41). Quoting Goethe, Schmitt notes that when it comes to geopolitics that "[a]ll petty things have trickled away, Only sea and land count here" (Schmitt, 2003, p. 37). What is key to Schmitt's critique of liberal international is the decisive role of land (and sea) appropriation for making sense of the spatial ordering of global politics. What matters is 'terrestrial being' and how this establishes the "normative order of the earth" (Schmitt, 2003, p. 39). Schmitt draws upon the geopolitical legacy of Halford J Mackinder, who famously detailed the 'pivotal' placement of Europe within world history, in examining the conditions of terrestrial being within global politics and international law. The two primary concepts advanced within The Nomos of the Earth concern the dynamic interaction between Großraum and Nomos. As Elden contends, "the term [Großraum] intends to grasp an area or region that goes beyond a single state (that is, a specific territory), to comprehend much larger scale spatial orderings, complexes or arrangements" (Elden, 2010, p. 18). Schmitt's account of history is decidedly linear, informed by all the privilege of the European legacy and the accompanying cultural capital of European historicising. With this linear approach to history, it is important to note how history moves from epoch to epoch and, in so doing, participates in what Hobson calls "the construction of an imaginary line of civilisational apartheid that fundamentally separated or split East from West" (Hobson, 2007, p. 94).

The postcolonial moment was largely absent from the revival of Carl Schmitt in the 1990s, with the emphasis on how Schmitt enables a critical architecture to contest the boundaries of liberal 
democracy and, in so doing, open up new potential for agonistic politics (Mouffe, 1999). Put simply, liberalism rejected the political and Schmitt's thinking on the vitality of the political provides us with an opportunity to resist the inexorable rise of global capitalism which finds itself woven into the very fabric of liberal democracy. More recently, the focus has shifted to the need to make sense of the plural constructions of order at the international level by thinking of international legal order through Schmitt's account of the 'pluriverse'. Mouffe has argued "in favour of a multipolar world order which recognizes diversity and pluralism and does not envisage the world as a 'universe' but as a 'pluriverse'" (Mouffe, 2009). The question as to how these diverse worlds are constructed, alongside the geopolitical contours of existing orders, raises important questions about the placement of religion and culture within this 'global' spatial order. Schmitt's focus on land-appropriation as the vehicle of (geopolitical) world history acknowledges the importance of the spatial ordering of world politics through nomos. It is important to note that land-appropriation is a material process of history, rather than just a concept or way of thinking about the construction of international order (Schmitt, 2003, p. 82). As Schmitt notes, "[t]he many conquests, surrenders, occupations, annexations, cessions, and successions in world history either fit into an existing spatial order of international law, or exceed its framework and have a tendency, if they are passing acts of brute force, to constitute a new spatial order of international law" (Schmitt, 2003, p. 82).

What is significant about Schmitt's account of international law and, more crucially, why this is relevant to contemporary scholarship within International Relations is the material focus on the how the 'contours of the earth emerged as a real globe' (Schmitt, 2003, p. 86). Nonetheless, underneath this material approach is an acknowledgement that the shifting frontiers of geopolitical power have been shaped by non-material elements. We cannot look at Empire in isolation from religion, as it is evident that the shared meanings of global order have developed through different religion, faith, and civic traditions. As Phillips notes, "[i]nternational orders are composed first of a web of shared meanings that make the exercise of authoritative power possible between polities" (Phillips, 2011). Schmitt directs us to focus on the amity lines of global politics (that is, how friends can be differentiated from enemies in concrete political groupings). "From the $16^{\text {th }}$ to the $20^{\text {th }}$ century," Schmitt notes, "European international law considered Christian nations to be the creators and representatives of an order applicable to the Earth" (Schmitt, 2003, p. 86). Schmitt argues that "[c]ivilization was synonymous with European civilization" and "Christian princes and peoples of Europe considered Rome or Jerusalem to be the centre of the earth" (Schmitt, 2003, pp. 86-87). What Schmitt refers to as 
'global linear thinking' brought about new ways of thinking about the division of the world into different political units. World maps do not just reflect the geographical contours of the earth, they provide a structure for making sense of shared meanings in different spaces and places. As Schmitt argues, the mapping of the earth carries with it "politically presupposed spatial concepts" which not only reflect the dominant power relations of the Judeo-Christian world, but also reveal the colonisation of 'new worlds' by 'old worlds' (Schmitt, 2003, p. 90).

Schmitt talks about the 'detheologization' of European international during from the $16^{\text {th }}$ to $19^{\text {th }}$ century, largely due to an agreed settlement between Church and State in Western Europe after the reformation (Schmitt, 2003, p. 41). Nonetheless, international law may have been 'secularised' but the territorial groupings of world politics reflect the divisions of the earth which were comprehensively and violently demarcated through Empire and colonialism. Schmitt's Theory of the Partisan also provides us with a deeper reflection on the contours of enmity (and mythologies of the enemy) in global politics. Slomp argues that for Schmitt, "political theology inspires the basic beliefs that underpin the friend/enemy principle, namely the two-fold conviction that firstly we must try to limit hostility but must not try to overcome it and that secondly we must never let morality and politics mix" (Slomp, 2009). Whilst it is evident that Schmitt's account of enmity in both The Concept of the Political and Theory of the Partisan helps to tap into the mythological dimensions of enmity, especially in relation to contemporary reflections on terrorism, it is important to link Schmitt's account of political theology to his broader geopolitical worldview. Slomp notes that "[e]ven though Schmitt is probably more stimulating when he is polemical than when he toys with theology or with philosophy, his attempt to offer explanations, sometimes very elaborate, for holding his specific belief system is worthy of attention" (Slomp, 2009, p. 135). Slomp raises a serious question about whether Schmitt is, in fact, just playing around with theology at the margins or whether his concrete worldviews are informed by a political theology of the exception which conditions his reading of the landscape of international law and sovereignty in world politics. If the former, then Schmitt's predilection for the transcendental can be understood as a quirk of an otherwise fascinating, albeit dangerous, geopolitical thinker. If the latter, then Schmitt's political theology is inseparable from his more compelling work on the historical sociology of spatialised international legal order.

Odysseos offers an insightful reading of the 'dangerous ontologies' at work not just in Schmitt's political writings but also in the broader tradition of political realism within IR itself. Arguing 
that "Schmitt challenged the possibility of transcending the state of nature in international politics and, hence, called into question the very possibility that the liberal practice of law and the establishment of international institutions could promote peace and prevent war" Odysseos demands we pay closer attention to the way in which politics and ethics are enabled as 'partitioned' concepts within IR theory (Odysseos, 2002, p. 412). Schmitt's endorsement of the strict division between politics and ethics is a prominent feature of his account of international legal order and the requirement that sovereignty exercises not through a normative lens but through the exercise of power itself. With this in mind, a more detailed reading of Schmitt's account of political theology, as presented in the current article, can direct us to think about sovereignty in different ways. In engaging with Schmitt's theopolitical framework of international legal order, one which observes the continuities between Church and State rather than its complete separation, we do not need to accept that sovereignty is a religious principle within global politics. We do, however, discover how discourses of sovereignty have emerged from dominant world groupings and how these same spatial orders contain within them assumptions about both the emergence of power and legitimacy in world politics. Schmitt's account of geopolitics directs us to focus on the changing contours of world history and how these are continually reconfigured through war, conflict and violence in world politics.

In Constitutional Theory, Schmitt defines international law as "the sum of customary or conventionally recognized rules for these relations of mere coexistence" (Schmitt, 2008, p. 381). This text provides the direct link between Schmitt's account of 'the political' (where the friend and enemy grouping provides the basis for politics) and his account of the spatial ordering of sovereignty in world politics. Sovereignty is directly linked to the process of differentiating friend from enemy: "The question of sovereignty, however, is the decision on an existential conflict" (Schmitt, 2008, p. 389). This 'existential conflict' is at the heart of sovereignty, as Schmitt argues, "the enemy is something existentially other and foreign, the most extreme escalation of the otherness, which in the case of conflict leads to the denial of its own type of political existence" (Schmitt, 2008, p. 394). For Schmitt, political existence is nullified by the foreign: "the will to self-determination, which belongs to anything that exists politically, is nullified or endangered only through interference that is foreign in existential terms" (Schmitt, 2008, p. 394). We may not like Schmitt's foray into theology or philosophy, we may think it peripheral to his broader spatial-political project, but the emphasis placed on the extremes of political existence requires a closer reading: Who is authorised to make political decisions and at what level? What type of framework of legitimation has developed to make sense of the 
workings of modern sovereignty and how are these linked to questions of legal capacity? Where are the limits of the different (and shared) accounts of sovereignty within the international system? The next section seeks to unpack the three dimensions of sovereignty-theopolitical, juristic, and popular-and how these are linked to theopolitical utterances.

\section{Outing theology within international order}

The value of Schmitt's account of sovereignty (as a concept which is almost always tested at its limits) is to reveal the religious workings of secular concepts within both the theory and practice of International Relations. Benhabib is dismissive of the 'unthought' dimension of theology and religion within political communities, practices of statecraft and within the spatialized logics of global politics (Benhabib, 2010, p. 454). Along with Habermas and Rawls, Benhabib treats religion as an identity constituted through differences within multicultural society. There are clear limits to this way of thinking about religion and theology in global politics: firstly, the resolution to the problem of religious difference are encased in both ethnocentrism and Eurocentrism; secondly, the values of religion must be accommodated, accounted for and negotiated within the realm of consensus based reason; thirdly, the method of resolution failures to direct those who are the most ardent critics of specific religious practices or religions to reflexively examine their own 'secular' and/or 'religious' ontologies. For this reason, agreeing with Nicholas Rengger, "we have no understanding of how centrally the theological is still embedded in the modern and thus fail to understand the modern itself' (Rengger, 2013, p. 143).

For Rengger "taking the theological voice seriously offers a rich repository of ideas and avenues of investigation that International Relations would be foolish to ignore" (Rengger, 2013, p. 153). An example of how we can take the theological voice seriously (without mandating scholarship within global politics to embrace religion) is to carefully read the historical sociology of sovereignty through a range of complex, contradictory political registers. The liberal abandonment of the exception is the secularization of sovereignty through the machinery of the modern state. Carl Schmitt is concerned that the modern theory of the state involves the rationalization of authority, endangering the very concept of sovereignty (that is, who is enabled to make decisions) by attempting to justify the authority of the state through rational or semi-rational means. According to Schmitt, "viewed from the history of ideas, the development of the nineteenth-century theory of the state displays two 
characteristic moments: the elimination of all theistic and transcendental conceptions and the formation of a new concept of legitimacy" (Schmitt, 1985, p. 51). For Schmitt, attempting to give sovereignty a foundation in the everyday, expressed in the concept of popular sovereignty, is inherently problematic for Schmitt. Likewise, the routine placement of sovereignty through the rule of law (whether at the domestic or international level) fails to appreciate the godlike practices of sovereignty in global politics. That is to say, the constitutive foundations of sovereignty cannot be expressed popularly; sovereignty is the divine expression of the metaphysical realm, emerging concretely through the exception. The dilemmas of this theopolitical account of sovereignty should be duly noted, especially as it fails to enact limits on the exercise of political power. Yet the limits of both popular sovereignty and juristic sovereignty should also be thinly understood, as the capacity to exercise brute expressions of power is not necessarily overcome within both democratic theory and/or liberal international law.

Stuart Elden has warned "that anointing of Schmitt as a geopolitical theorist with contemporary relevance is ... a serious error, intellectually and politically" (Elden, 2010, p. 24). The basis for this claim concerns the importance of looking at Schmitt's geopolitical writings against the backdrop of his broader writings. This article, it should be noted, does not seek to anoint Schmitt as the grand theorist of sovereignty. On the contrary, in demanding a closer reading of sovereignty as it relates to the secular and non-secular domain the emphasis is on asking for greater awareness of how meanings about power, state, and territory resonate through established practices in global politics. Religion is not a variable within the broader domain of International Relations, but a constitutive domain of global order(s) itself. It may appear in different places and spaces in varying degrees, but the drive towards secularism as the sine qua non of progressivism in global politics needs to be decisively contested.

We know in Schmitt's account of political theology that the 'miracle need not be true' and in this regard we should pay attention to George Sorel's understanding of the power of myth in reflecting on human conduct within International Relations. Sorel noted that "myths must be judged as a means of acting on the present" (Sorel, 1999, p. 116). In demanding that we think about sovereignty as constituted through multiple domains this article is advocating for an understanding of sovereignty which is alert to mythologies of theology as equally as the mythologies as secularism. 
There exists a rich body of international political theory which explicitly draws upon a liberal canon as a basis for determining the rules, norms, and scope of International Relations. This article, in drawing upon Schmitt's theopolitical account of sovereignty, seeks to unpack the ways in which registers of sovereignty should not be fashioned exclusively in the image of liberalism and/or secularism. Whether we draw upon the writings of Thomas Hobbes, John Locke and/or Immanuel Kant to understand the liberal dimensions of global order we need to also understand how alternative readings of global order are possible and likely from a range of theoretical perspectives. We have become adept at reading global politics through the lens of orthodoxy and flattening our horizons of international order to a limited set of ideological domains: realist, liberal, critical, postpositivist, and so it goes. Understanding how the seemingly secular exists alongside the religious, the theological, and the spiritual is not to endorse theology above other modes of thinking and being in global politics. On the contrary, understanding how secularism has in fact contributed to a misreading of religion is key to engaging religion at not just the regulative level but also the constitutive level within International Relations theory. As Fahy and Haynes note "[s]ecularization theory in social science (or the broader category of modernization theory in political science) is often presented as the main culprit" (Fahy \& Haynes, 2018). This article cautions against the mythologies of secularism determining the legitimacy and/or validity of sovereignty on the basis of secularity alone. Allocating sovereignty to a secular domain, in which laws seemingly regulate the conduct of and between states, is part of a longstanding trend to present modernity as the progressive current of international relations theory.

This progressive association of liberalism as a forward-looking, forward thinking theory of international politics can be demonstrated in G John Ikenberry's current concern about the politics of backlash in global politics. As Ikenberry argues "[i]n the nineteenth century, liberal internationalism was seen in the movements towards free trade, international law, collective security and the functional organization of the western capitalist system" (Ikenberry, 2018, p. 9). Furthermore, Ikenberry claims that liberal internationalism is "a way of thinking about and responding to modernity-its opportunities and its dangers" (Ikenberry, 2018, p. 9). In his discussion of the anti-liberal backlash there is no mention of religion or contemporary movements driven to embrace a particular cause on the basis of religion or nationalism itself. In Ikenberry's liberal international creed, moves towards an international order are progressive, secular, and inherent legacies of our post-Enlightenment world. Challenges to this order are backward and must be countered with an even more open, even more institutionalised 'rules-based order' which is 'progressively orientated' (Ikenberry, 2018, p. 12). The strange absence of religion, of faith, and/or 
of nationalism from this world looks more akin to the 'family' snapshots described by Ken Booth: "just as family snaps help us tell different (and sunnier) family stories from the daily routines of life, so international relations snapshots change, exclude and massage reality" (Booth, 1995, p. 104). The question needs to be asked, would those subject to the violence of our territorialised borders or suffering at the hands of a corrupt government recognise this rules-based order? Selfmeanings might be important for academic debate, but in terms of making sense of the broader practices within international society we need to be cognisant of the fact that methodological pluralism is not a whim but actually a function of the plural worlds in which we live. Secularism might be regarded as the Emperor's New Clothes of world politics; so enmeshed in a desire to establish a progressive narrative of global order that it overlooks how constitutive of global order religion and theology actually are.

This does not mean that Carl Schmitt's account of sovereignty should necessarily be deployed for establishing an account of International Political Theology within global politics. But there is value in reflecting upon how religion has been encoded with the professional space of International Relations at the same time as operating as a discourse of threat within the practices of contemporary security politics. As noted by Kubálková, "religions have either been treated as one amongst many epistemic communities, or as non-government or transnational organisations" (Kubálková, 2000). Taking religion more seriously, as a constitutive element of political communities, would involve unpacking the practices, processes and concepts which sustain global order. As Duncan Bell has identified in relation to conceptions of Empire in Victorian thought, the failure to examine the theoretical and methodological conditions which enable empire has been a primary weakness of scholarship within International Relations. The Victorian imperial imagination, Bell suggests, was sustained through political claims about religion, civilization and theories of progress (Bell, 2006, p. 287).

Echoing this claim, Scott Thomas has also sought to engage theology for extending the reach of critical theory within global politics. Scott's alignment of theology with critical theory, involving a rejection of positivist working methodologies, demands a reassessment of the placement of religion within the discipline of International Relations. Even the 'religious turn' (with 9/11 symbolically rendered as the pathologizing moment for religion in global politics) has reduced religion to something which is 'to be studied' but seldom understood on its own terms. Thomas calls for a rethinking of the placement of religion in global politics, especially 
as the worlds in which global inequalities are most pronounced (including structural and physical violence) are communities with religious commitments: "All life is not only lived within theories; far more importantly is the fact that for most of the people in the world all life is lived within theologies and spiritualities" (Thomas, 2010, p. 509).

It should be noted that the injunction to take religion seriously can operate at many levels; from a reflexive engagement with the historical evolution of both political and religious ideas within international political thought (see Bell and Rengger) or as a call for reflection on the role of prayer and religious practices within global politics (see Thomas and Kubálková). Expressing sovereignty as an expression of the political theology, conditioned by the dictates of the exception, challenges both the rationalized accounts of legal sovereignty (juristic sovereignty) and popularized accounts of sovereignty (popular sovereignty) which are typically presented as definitive accounts of 'modern' sovereignty.

Mirroring Schmitt's narrative of the evolution of sovereignty, Morgenthau has noted that " $[t]$ he modern conception of sovereignty was first formulated in the latter part of the sixteenth century with reference to the new phenomenon of the territorial state" (Morgenthau, 1960, p. 312). Whilst sovereignty may operate as a 'political fact' for thinkers such as Morgenthau, it is important to recognise how the seemingly secularity of contemporary scholarship in International Relations can be understood through the historical lens of prior forms of theocracy and theodicy. The modernity of international legal order, its symbolic gesture towards progressivity and impartiality, must be categorically rejected as an epistemological basis for devising systematic theory within International Relations. As argued by Paipais (2016) "it is crucial to revisit the fragmented theological tropes behind contemporary anthropologies and concomitant philosophies of history precisely because these tropes are not readily legible as theological anymore". Theorists of International Relations have looked to UFO's to make intelligible the operating logics of insecurity in world politics. For many, the claim that "sovereignty is the province of humans alone" is largely an uncontroversial one (Wendt \& Duvall, 2008, p. 607). What follows from this understanding of sovereignty is unashamedly anthropomorphic in its hierarchies of value: "Animals and Nature are assumed to lack the cognitive capacity and/or subjectivity to be sovereign; and while God might have ultimate sovereignty, even most religious fundamentalists grant that it is not exercised directly in the temporal world" (Wendt \& Duvall, 2008, p. 607). Yet in examining the theopolitics of sovereignty, whether as an intended or unintended expression of decisionist capacity in global 
politics, it is important to see how theologies of order still emerge through theopolitics.

Morgenthau's observation that scholars of International Relations are often unaware that "they meet under an empty sky from which the gods have departed" should be explored more philosophically as a political claim about the origins of sovereignty. In cautioning against the 'religion as a variable' approach to religion in global politics, the intention is to underscore the importance of reflexive engagement with disciplinary knowledges that constitute the normative and analytical agenda of scholarship in global politics. Theology (and theopolitics) is one such disciplinary knowledge and reducing it down to a variable 'to be studied' is not sufficient for the task of thinking ethically and reflexively about how secular frameworks are themselves expressions of religious orders. We should remind ourselves of how everyday concepts in global politics are endowed with the reverence of the sacred in International Relations. Nationalism can be understood as a 'secular' religion; or as Morgenthau observed in relation to nationalist universalism: "It [nationalism] is a secular religion, universal in its interpretation of the nature and destiny of man and in its promise of salvation for all mankind" (Morgenthau, 1960, p. 338).

Theology (and theopolitics) needs to be understood as a disciplinary knowledge within the broad field of International Relations. A sensitive analysis of the origins of sovereignty thereby conditions the types of questions we ask about the constitution of world politics more widely. In an age of populism, where the complexity of religious orders are reduced down to binary categories of good versus evil, we do not need to accept the secular mythology of IR as valueneutral, unencumbered from the norms and values which have descended from a long tradition of European statehood and subsequently 'exported' to across the world. We do, however, need to refuse the 'religion as a variable' approach to global politics by encouraging reflexive forms of scholarship which allow us to rethink the conceptual frameworks (including theological) that condition our thinking on identity and difference within world politics. Wouldn't it be ironic if the secular worlds we have constructed, to politically demarcate our friends from our enemies, came to be nothing more than the received doctrine of European statecraft and all its theological (and violent) preoccupations?

\section{Bibliography}

Bell, D. S. A., 2006. Empire and International Relations in Victorian Political Thought. The Historical Journal, 49(1), pp. 281-298. 
Benhabib, S., 2010. The return of political theology: The scarf affair in comparative constitutional perspective in France, Germany and Turkey. Philosophy Social Criticism, 36(3-4), pp. 451-471.

Booth, K., 1995. Human Wrongs and International Relations. International Affairs, 71(1), pp. 103-126.

Brown, C., Nardin, T. \& Rengger, N. eds., 2002. International Relations in Political Thought. Cambridge: Cambridge University Press.

Cavanaugh, W. T., 2002. Theopolitical Imagination: Christian Practices of Space and Time. London: Continuum.

Cavanaugh, W. T., 2009. The Myth of Religious Violence: Secular Ideology and the Roots of Modern .... Oxford: Oxford University Press.

Chowdhury, A. \& Duvall, R., 2014. Sovereignty and Sovereign Power. International Theory, 6(2), pp. 191-223.

Elden, S., 2010. Reading Schmitt geopolitically: Nomos, territory and Großraum. Radical Philosophy, Issue 161, pp. 18-26.

Elden, S., 2010. Reading Schmitt Geopolitically: Nomos, Territory and Großraum.

May/June(161).

Fahy, J. \& Haynes, J., 2018. Introduction: Interfaith on the World Stage. The Review of Faith \& International Affairs, 16(3), pp. 1-8.

Fukuyama, F., 2011. The Origins of Political Order: From Prehuman Times to the French Revolution. London: Profile Books.

Hobson, J. M., 2007. Is critical theory always for the white West and for Western imperialism? Beyond Westphilian towards a post-racist critical IR. Review of International Studies, Volume 33, pp. 91-116.

Ikenberry, G. J., 2018. The end of liberal international order?. International Affairs, 94(1), pp. 7-23.

Kelsen, H., 1941. The Pure Theory of Law and Analytical Jurisprudence. Harvard Law Review, 55(1), pp. 44-70.

Kelsen, H., 1969. Sovereignty and International Law. In: W. J. Stankiewicz, ed. In Defence of Sovereignty. New York: Oxford University Press.

Kubálková, V., 2000. Towards an International Political Theology. Millennium: Journal of International Studies, 29(3), pp. 675-704.

Louma-Aho, M., 2009. Political Theology, Anthropomorphism, and Person-Hood of the State: The Religion of IR. International Political Sociology, 3(3), p. 293-309. 
Luoma-Aho, M., 2012. God and International Relations. New York: Continuum.

Mavelli, L., 2012. Security and Secularization in International Relations. European Journal of International Relations, 18(2), pp. 177-199.

Moore, T., 2010. The paradox of the political: Carl Schmitt's autonomous account of politics. The European Legacy, 15(6), pp. 721-734.

Morgenthau, H., 1960. Politics Among Nations. New York: Alfred A. Knopf.

Mouffe, C., 1999. The Challenge of Carl Schmitt. London: Verso.

Mouffe, C., 2009. Democracy in a Multipolar World. Millennium: Journal of International Studies, 37(3), pp. 549-561.

Niebuhr, R., 2005. Moral Man and Immoral Society: A Study in Ethics and Politics. London: Continuum .

Odysseos, L., 2002. Dangerous ontologies: the ethos of survival and ethical theorizing in International Relations. Review of International Studies, 28(2), pp. 403-418.

Odysseos, L. \& Petito, F., 2006. Introducing the International Theory of Carl Schmitt: International Law, International Relations, and the Present Global Predicament(s). Leiden Journal of International Law, Volume 19, pp. 1-7.

Paipais, V., 2016. First image revisited: human nature, original sin and international relations. pp. 1-25.

Phillips, A., 2011. War, Religion and Empire: The Transformation of International Orders. Cambridge: Cambridge University Press.

Rengger, N., 2013. On theology and international relations: World politics beyond the empty sky. International Relations, 27(2), pp. 141-157.

Sandal, N. A. \& James, P., 2011. Religion and International Relations theory: Towards a mutual understanding. European Journal of International Relations, 17(3), pp. 3-25.

Schmitt, C., 1985. Political Theology: Four Chapters on the Concept of Sovereignty. Chicago: University of Chicago Press.

Schmitt, C., 1987. The Legal World Revolution. Telos, June, Issue 72, pp. 73-89.

Schmitt, C., 1996. The Concept of the Political. Chicago: Univeristy of Chicago Press.

Schmitt, C., 2003. The Nomos of the Earth. New York: Telos.

Schmitt, C., 2008. Constitutional Theory. Durham: Duke University Press.

Schmitt, C., 2011. Writings on War. Cambridge: Polity Press. 
Schmitt, C., 2015. Land and Sea. New York: Telos.

Shakman Hurd, E., 2007. The Politics of Secularism in International Relations. New Jersey: Princeton University Press.

Slaughter, A.-M., 1995. Liberal International Relations Theory and International Economic Law. American University International Law Review, 10(2), pp. 717-743.

Slomp, G., 2009. Carl Schmitt and the Politics of Hostility, Violence and Terror. Basingstoke: Palgrave.

Sorel, G., 1999. Reflections on Violence. Cambridge: Cambridge University Press.

Suganami, H., 2007. OB] Understanding Sovereignty through Kelsen/Schmitt. Review of International Studies, July, pp. 511-530.

Thomas, S. M., 2010. Living Critically and 'Living Faithfully' in a Global Age: Justice, Emancipation and the Political Theology of International Relations. Millennium: Journal of International Studies, 39(2), pp. 505-524.

Tilly, C., 1985. War Making and State Making as Organized Crime. In: P. B. Evans, D. Rueschemeyer \& T. Skocpol, eds. Bringing the State Back In. Cambridge: Cambridge University Press, pp. 169-191.

Walzer, M., 2015. Just and Unjust Wars: a Moral Argument with Historical Illustrations. 5th Edition ed. New York: Basic Books.

Weber, M., 2004. The Vocation Lectures. Indianapolis: Hackett Pub.

Wendt, A. J. \& Duvall, R., 2008. Sovereignty and the UFO. Political Theory, August, 36(4), pp. 607-633. 
